\title{
PENGGUNAAN KONSEP RULES-IN-USE OSTROM DALAM ANALISIS PERATURAN PEMANFAATAN AIR DI KAWASAN KONSERVASI: STUDI KASUS TAMAN NASIONAL GUNUNG GEDE PANGRANGO
}

\section{(The Use of Ostrom Rules-in-use Concept in the Regulatory Analysis of Water Utilization in Conservation Areas: Case Study Gunung Gede Pangrango National Park)}

\author{
Rudy Dwi Siswantoro ${ }^{1}$, Hariadi Kartodihardjo², Hendrayanto ${ }^{2}, \&$ Dudung Darusman ${ }^{2}$ \\ 'Program Studi Ilmu Pengelolaan Sumberdaya Alam dan Lingkungan, Institut Pertanian Bogor, \\ Kampus IPB Baranangsiang, Bogor, Indonesia; email: rudy_siswantoro@apps.ipb.ac.id \\ ${ }^{2}$ Departemen Manajemen Hutan, Fakultas Kehutanan, Institut Pertanian Bogor Jl. Raya Dramaga, \\ Kampus IPB Dramaga, Bogor, Indonesia; email: hakabgr@gmail.com;hendrayanto@gmail.com; \\ dudungdarusman@gmail.com
}

Diterima 3 Februari 2021, direvisi 4 Juni 2021, disetujui 16 Juni 2021

\begin{abstract}
This study aims to analyze the substantial weaknesses of water utilization regulations in wildlife reserves, national parks, forest parks, nature tourism parks, and their effects on individual or organizational decisionmaking and actions. The research location is in the area of Taman Nasional Gunung Gede Pangrango (TNGGP). The analysis of this research is limited to Environment and Forestry Ministerial Regulations No. P.18/MENLHK/ SETJEN/KUM.1/4/2019, Law No. 17 of 2019, and Environment and Forestry Ministerial Regulations No. P.6/ MENLHK/SETJEN/KUM.1/1/2020. Regulatory analysis is carried out by identifying the characteristics of content of the regulations and comparing them with the conditions of water utilization in TNGGP to find out the implications of regulations on participant behavior and performance. Issues and problems are collected through interviews with participants. Furthermore, the regulations are analyzed using Ostrom's rules-in-use concept. The findin, based on the concept is that there is a discrepancy in the three regulations that all regulate water utilization permits in the conservation areas. This is mainly due to weak institutional strengthening among decision makers as well as laws and regulations made according to the interpretation of the government which often do not consider the conditions of the community.
\end{abstract}

Keywords: Conservation area; Ostrom rule-in-use concept; regulation; water utilization.

\begin{abstract}
ABSTRAK
Penelitian bertujuan untuk menganalisis kelemahan-kelemahan substansial peraturan pemanfaatan air di suaka margasatwa, taman nasional, taman hutan raya, dan taman wisata alam serta pengaruhnya terhadap pengambilan keputusan dan tindakan individu atau organisasi. Lokasi penelitian di kawasan Taman Nasional Gunung Gede Pangrango (TNGGP), Bidang Wilayah Pengelolaan Cianjur dan Sukabumi. Analisis dibatasi pada pasal-pasal yang berkaitan dengan pengaturan pemanfaatan air di suaka margasatwa, taman nasional, taman hutan raya, dan taman wisata alam pada tiga peraturan yaitu Peraturan Menteri Lingkungan Hidup dan Kehutanan No. P.18/MENLHK/ SETJEN/KUM.1/4/2019, Undang-Undang No. 17 tahun 2019, dan Peraturan Menteri Lingkungan Hidup dan Kehutanan No. P.6/MENLHK/SETJEN/KUM.1/1/2020. Analisis dilakukan dengan cara mengidentifikasi karakteristik isi peraturan dan membandingkannya dengan kondisi pemanfaatan air di TNGGP untuk mengetahui implikasi peraturan terhadap perilaku dan kinerja partisipan. Isu dan permasalahan dikumpulkan melalui wawancara dengan para partisipan. Peraturan dianalisis dengan konsep rules-in-use Ostrom. Temuan dalam analisis peraturan berdasarkan konsep rule-in-use yaitu terdapat ketidak-sinkronan dalam ketiga peraturan mengenai perizinan pemanfaatan air di kawasan konservasi. Hal tersebut disebabkan lemahnya penguatan kelembagaan antar-para pengambil keputusan serta peraturan perundang-undangan yang dibuat menurut interpretasi Pemerintah seringkali tidak mempertimbangkan kondisi masyarakat.
\end{abstract}

Kata kunci: Area konservasi; konsep rule-in-use Ostrom; pemanfaatan air; peraturan. 


\section{PENDAHULUAN}

Kawasan Taman Nasional Gunung Gede Pangrango (TNGGP) memiliki peran yang sangat strategis sebagai daerah tangkapan air (catchments area) bagi daerah-daerah di bawahnya. Kawasan TNGGP menjadi salah satu andalan untuk mendukung pertumbuhan ekonomi wilayah sekitarnya.

Permasalahan pengelolaan sumber daya alam menjadi sangat penting dalam pembangunan ekonomi pada masa kini dan masa yang akan datang. Di lain pihak, sumber daya alam tersebut telah banyak mengalami kerusakan, terutama berkaitan dengan caracara eksploitasi guna mencapai tujuan bisnis dan ekonomi. Masalah ini muncul sebagai akibat dari terjadinya kemelut dari berbagai aktivitas pengurasan dan degradasi beberapa jenis sumber daya alam dan lingkungan hidup sebagai akibat dari pihak-pihak yang bertanggung-jawab di mana mereka telah melakukan kebijakan yang salah arah (misleading policy) (Anwar \& Rustiadi, 2000). Lemahnya kebijakan dalam pembangunan kehutanan sejauh ini ialah akibat dari kekeliruan dalam mendefiniskan masalah dan aspek-aspek kelembagaan pengelolaan hutan yang dianggap bukan masalah (Kartodihardjo, 2006b).

Hasil analisis Kartodihardjo (2006b) terhadap 124 makalah seminar dan publikasi menyimpulkan bawa akar masalah timbulnya permasalahan sumber daya alam dan lingkungan hidup terletak pada lemahnya hak terhadap sumber daya alam. Hal tersebut merupakan dampak dari masalah kegagalan penguatan kelembagaan.

Peters (2000) menyatakan bahwa "institution must become institution". Upaya perubahan kelembagaan yang dalam hal ini adalah aturan main dan instrumennya seringkali tidak diikuti oleh pembaruan landasan filosofi dan kerangka pikir yang digunakan. Akibatnya, peraturan bertambah, lembaga bertambah, nama lembaga diubah tetapi tipe kebijakan yang dijalankan tidak berubah sehingga tidak mengubah kinerja di lapangan. Seiznick (1957) dalam Peters (2000) mengatakan "institutionalization involves infusing a structure with value".

Dugaan masalah kegagalan penguatan kelembagaan pemanfaatan air yang intake dari kawasan TNGGP berkaitan dengan dua aspek. Pertama, policy narrative yang cenderung menganggap bahwa instrumen hukum atau aspek legalitas menjadi acuan utama, bahkan tunggal, dalam menyelesaikan masalah. Misalnya, ketika terjadi ketidaksesuaian antara Peraturan Menteri Lingkungan Hidup dan Kehutanan (Permen LHK) No. P.18 tahun 2019 tentang Pemanfaatan Air dan Energi Air di Suaka Margasatwa, Taman Nasional, Taman Hutan Raya, dan Taman Wisata Alam dengan Undang-Undang (UU) No.17 tahun 2019 tentang Sumber daya Air. Pengelola Balai Besar TNGGP (BBTNGGP) memilih sikap menunggu peraturan turunan dari UU tersebut sebagai penyelesaian masalah. Artinya, aspek legal dan kewenangan tidak selalu mempunyai regulating power yang cukup.

Kedua, peran pengelola BBTNGGP menjadi lemah akibat seringkali mementingkan luaran (output), bukan hasil (outcome). Pengelola BBTNGGP bekerja atas dasar peraturan perundangan yang berlaku yaitu mengacu pada kinerja aspek adminstrasi, contohnya mengadministrasikan persyaratan Ijin Usaha Pemanfaatan Air (IUPA) dan Ijin Pemanfaatan Air (IPA) sebagai pemenuhan syarat administrasi, bukan sebagai upaya pelestarian lingkungan. Persoalannya adalah bagaimana bersiasat menghadapi kondisi pertentangan aturan tersebut. Dalam jangka pendek, upaya yang dapat dilakukan adalah mengatasi terjadinya policy trap. Opsi kebijakan tersebut dapat dijalankan apabila kelembagaan dianggap sebagai masalah (Kartodihardjo, 2006a).

Peraturan dalam kelembagaan formal selalu dijadikan acuan pokok dalam prosesproses pengambilan keputusan. Salah satu pentingnya penekanan pengaruh peraturan terhadap pengambilan keputusan dan 
tindakan individu atau organisasi yaitu analisis kelembagaan seringkali digunakan untuk menganalisis dampak dari perubahan peraturan serta mencari solusi bagi kinerja negatif dari situasi aksi dengan pertimbangan bahwa mengubah peraturan akan lebih mudah dilakukan daripada mengubah kondisi biofisik dan karakteristik masyarakat (Ostrom \& Crawford, 2005). Menurut Cole (2017), memahami aturan hukum formal diperlukan untuk memahami interaksi sosial dan perilaku individu. Efektivitas implementasi suatu kebijakan dapat terjadi apabila kebijakan dirumuskan atas dasar masalah yang tepat dan terdapat kemampuan menjalankan solusinya di lapangan (Dunn, 2003).

Penelitian ini bertujuan untuk menganalisis kelemahan-kelemahan substansial peraturan pemanfaatan air di suaka margasatwa, taman nasional, taman hutan raya, dan taman wisata alam. Analisis dibatasi pada pasal-pasal yang berkaitan dengan pengaturan pemanfaatan air di suaka margasatwa, taman nasional, taman hutan raya, dan taman wisata alam pada peraturan yang menjadi acuan perizinan pemanfaatan air di kawasan TNGGP. Hasil analisis dapat digunakan sebagai arahan untuk menentukan langkah-langkah yang diperlukan dalam rangka meningkatkan kinerja kelembagaan pemanfaatan air di suaka margasatwa, taman nasional, taman hutan raya, dan taman wisata alam.

\section{METODE PENELITIAN}

\section{A. Kerangka Teoritis dan Pendekatan}

Penelitian difokuskan pada analisis peraturan dengan menganalisis kelembagaan. Instrumen analisis kelembagaan yang digunakan ialah konsep rules-in-use dalam Kerangka Kerja Analisis dan Pengembangan Kelembagaan (Institustional Analysis and Development/IAD-Framework). IAD-framework ialah instrumen analisis kelembagaan yang telah mendapat pengakuan luas di dunia internasional (Suwarno, Kartodihardjo, Kolopaking, \& Soedomo, 2015). Komponen rules-in-use merupakan instrumen kebijakan yang dapat digunakan untuk menciptakan dampak yang diharapkan (Birkland, 2001). Contoh penggunaan konsep rules-in-use Ostrom ialah Suwarno et al. (2015) untuk menganalisis kelemahan peraturan pembentukan organisasi Kesatuan Pengelolaan Hutan Lindung (KPHL) dan Kesatuan Pengelolaan Hutan Produksi (KPHP).

IAD-framework merupakan pendekatan terpadu yang bertujuan untuk menjelaskan hubungan antara pola-pola interaksi dari para pelaku di tengah-tengah sejumlah kendala kelembagaan yang ada (Sabatier, Leach, Lubell, \& Pelkey, 2005). Di dalam kelompok variabel eksogen (exogenous variables) kerangka kerja IAD terdapat komponen rulesin-use atau aturan-aturan yang digunakan (Gambar 1). Aturan-aturan yang digunakan adalah aturan yang ditunjuk oleh partisipan jika mereka diminta untuk menjelaskan dan membenarkan tindakan yang mereka lakukan kepada partisipan lain (Ostrom, Gardner, \& Walker, 2006).

Konsep ini dapat digunakan untuk menganalisis isi peraturan dalam hubungannya dengan struktur situasi aksi yang terbentuk, perilaku yang terjadi, dan kinerja yang dihasilkan dalam proses pengaturan pemanfaatan air di TNGGP. Ostrom membagi aturan-aturan yang digunakan ke dalam tujuh jenis peraturan, yaitu aturan posisi, aturan keanggotaan, aturan pilihan, aturan agregasi, aturan informasi, aturan lingkup, dan aturan biaya-manfaat. Klasifikasi ini berkaitan dengan unsur-unsur struktur situasi aksi (para partisipan, posisi, pilihan tindakan, kontrol, informasi, hasil atau dampak, dan biayamanfaat) di dalam arena aksi. Hubungan antara unsur-unsur rules-in-use dengan unsurunsur situasi aksi ditampilkan pada Gambar 2. 


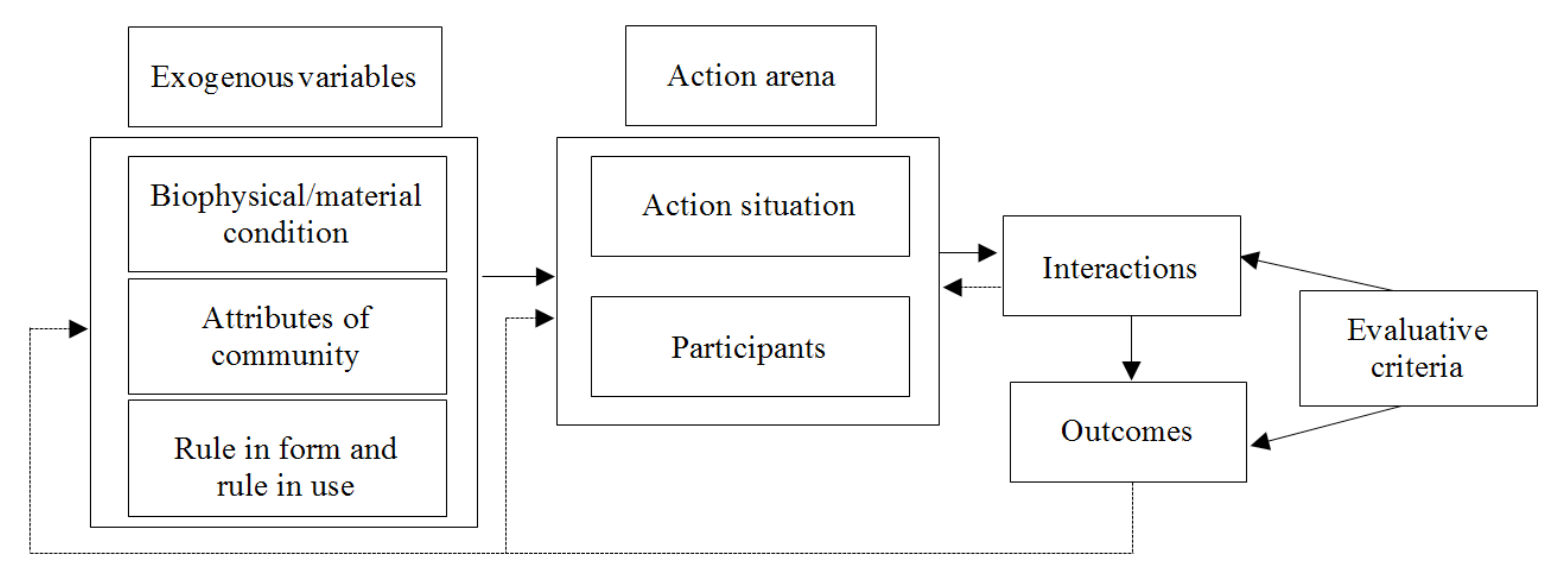

Sumber (Source): Ostrom et al. (1994) dalam Ostrom (2005)

Gambar 1 Kerangka kerja IAD

Figure 1 IAD framework.

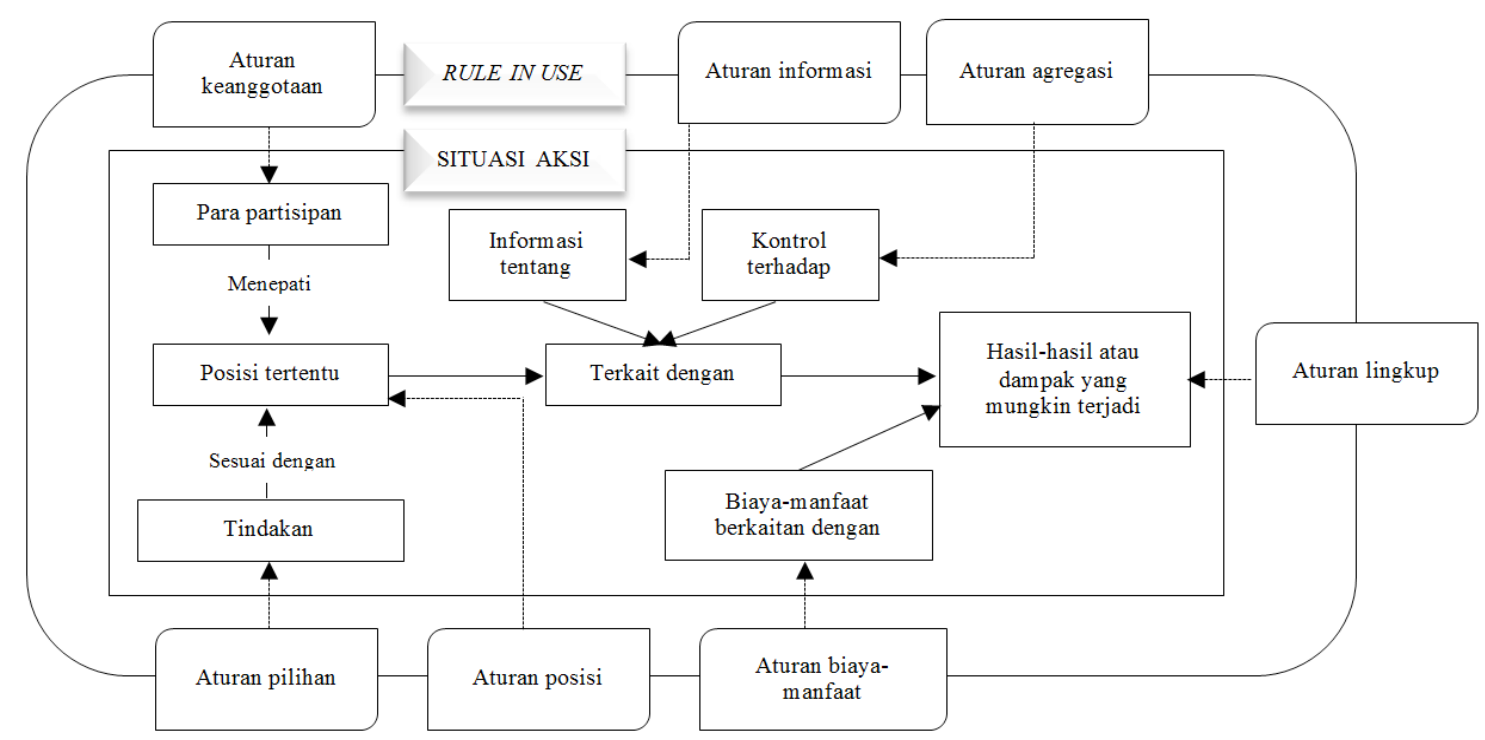

Sumber (Source): Ostrom (2005)

Gambar 2 Hubungan antara rule-in-use dengan unsur-unsur situasi aksi

Figure 2 Relation between rules-in-use with the elements of the action situation.

\section{B. Metode Pengumpulan dan Analisis Data}

Penelitian dilaksanakan pada bulan Desember 2019 sampai Februari 2020. Lokasi penelitian di Bidang Wilayah Pengelolaan Cianjur dan Sukabumi, TNGGP. Terdapat tiga peraturan yang dikaji, yaitu Permenhut No. P.18/2019 tentang Pemanfaatan Air dan Energi Air di Suaka Margasatwa, Taman Nasional, Taman Hutan Raya, dan Taman
Wisata Alam; UU No. 17/2019 tentang Sumber Daya Air; serta Permen LHK No. P.6/2020 tentang Pelimpahan Kewenangan Penerbitan Perizinan Berusaha Bidang Lingkungan Hidup dan Kehutanan Kepada Kepala Badan Koordinasi dan Penanaman Modal (BKPM).

Penelitian didahului dengan wawancara mendalam kepada main actor dalam proses perizinan pemanfaatan air di TNGGP yaitu 
staf BBTNGGP dan kepala resor (struktural BBTNGGP yang paling dekat dengan masyarakat). Analisis peraturan dilakukan dengan cara mengidentifikasi karakteristik isi peraturan dan membandingkannya dengan kondisi pemanfaatan air di TNGGP untuk mengetahui implikasi peraturan terhadap perilaku dan kinerja partisipan. Peraturan dianalisis dengan konsep rules-in-use (Ostrom, 2005).

\section{HASIL DAN PEMBAHASAN}

\section{A. Karakteristik Sumber Daya Alam dan Pengelolaannya}

Kondisi TNGGP sebagai andalan sumber mata air bagi daerah sekitarnya mendorong para pihak merasa memiliki hak untuk memanfaatkan air dari TNGGP secara bebas. Ostrom (2008) menyebutnya sebagai commonpool resources (CPR) dengan karakteristik menghasilkan manfaat yang dapat dinikmati oleh orang banyak tanpa dapat dikecualikan (non excludable). Karakteristik lain dari CPRs yaitu substractability, jika satu aktor menggunakannya maka tindakan tersebut menghilangkan atau mengurangi kemampuan aktor lain untuk juga menggunakan sumber daya yang sama (Weeden \& Chow, 2012).

Sejak tahun 2006 kegiatan pemanfaatan air di TNGGP dikelola berdasarkan konsep kemitraan melalui pembentukan kelembagaan Forum Peduli Air (FORPELA)-TNGGP yang beranggotakan pihak pemanfaat air TNGGP dengantujuanusaha.Kemitraaninidiwujudkan dalam bentuk perjanjian kerjasama atau Memorandum of Understanding (MoU) antara pihak pemanfaat dan pihak pengelola kawasan yaitu BBTNGGP. Keterlibatan pihak pemanfaat air dalam MoU tersebut dibangun sebagai bentuk tanggung jawab bersama dalam upaya menjaga kelestarian sumber daya air melalui skema jasa lingkungan Payment for Environmental Services (PES) (FORPELA, 2009).

FORPELA berangsur-angsur tidak lagi berfungsi sejak ditetapkannya Permenhut
No. P.64/2013, yang selanjutnya diperbarui dengan Permen LHK No. P.18/2019. Peraturan ini membagi pemanfaat air menjadi pemanfaat non komersial dan komersial serta mengatur seluruh pemanfaat agar memiliki Izin Pemanfaatan Air (IPA) dan Izin Usaha Pemanfaatan Air (IUPA). Permenhut No. P.64/2013 dan Permen LHK No. P.18/2019 tidak memiliki perbedaan yang signifikan. Pada Permen LHK No. P.18/2019, proses dan penerbitan izin komersial dilakukan melalui Perizinan Berusaha Terintegrasi secara Elektronik atau Online Single System (OSS). Permen LHK No. P.18/2019 diterbitkan pada April 2019; pada Oktober 2019, terbit peraturan baru yaitu UU No. 17/2019 tentang Sumber Daya Air yang membatasi pemanfaatan air di KSA dan KPA hanya untuk penggunaan non komersial. Hingga penelitian ini selesai dilaksanakan, pihak BBTNGGP menunda pemrosesan izin pemanfaatan air komersial seraya menunggu peraturan tentang petunjuk teknis.

\section{B. Peraturan dalam Pemanfaatan Air di TNGGP}

Pemanfaatan air di kawasan TNGGP dibagi menjadi dua macam menurut Permenhut No. P.64/2013 dan Permen LHK No. P.18/2019 yaitu pemanfaatan non komersial dan komersial. Pemanfaatan air non komersial yaitu pemanfaatan air untuk kebutuhan pokok hidup sehari-hari. Masyarakat sekitar kawasan memanfaatkan air untuk keperluan rumah tangga, kelompok tani, serta sarana prasarana umum seperti musala, masjid, dan lain-lain. Pemanfaatan air komersial yaitu pemanfaatan air untuk kepentingan komersial atau usaha, meliputi usaha di bidang pertanian, usaha bunga, PAM (penyediaan air minum) komersial, usaha peternakan, vila, hotel, dan lain-lain.

Berdasarkan hasil wawancara mendalam dengan staf BBTNGGP, perizinan atas pemanfaatan air dari kawasan TNGGP masih mengacu pada Permenhut No. P.64/2013. Hal ini karena OSS untuk perizinan pemanfaatan 
air komersial yang diatur dalam Permen LHK No. P.18/2019belum siap digunakan sehingga proses perizinan masih dilakukan secara manual. Kedua peraturan ini mengatur bahwa setiap pemanfaat air non komersial harus memiliki IPA dan pemanfaat komersial harus memiliki IUPA. Namun demikian, UU No. 17 tahun 2019 tentang Sumber Daya Air membatasi pendayagunaan sumber daya air di KSA dan KPA hanya untuk pemenuhan kebutuhan pokok sehari-hari yang tidak dimanfaatkan sebagai bentuk usaha.

Peraturan Menteri LHK No. 6 tahun 2020 mengatur tentang Pelimpahan Kewenangan kepada Badan Koordinasi Penanaman Modal (BKPM) sebagai Penerbit Perizinan Berusaha Bidang Lingkungan Hidup dan Kehutanan dengan berpedoman pada peraturan dan ketentuan teknis tata cara perizinan yang ditetapkan oleh Menteri LHK. Peraturanperaturan tersebut dirasa tumpang-tindih. Berdasarkan hasil wawancara dengan Kepala Resor, semenjak terbit UU No. 17 tahun 2019 maka pengurusan IUPA ditangguhkan sampai adanya peraturan turunan atas UU tersebut atau terdapat petunjuk teknis dari KLHK.

\section{Hasil Analisis Peraturan}

Hasil analisis peraturan yang berisi ringkasan pasal-pasal yang berkaitan dengan pengaturan pemanfaatan air di suaka margasatwa, taman nasional, taman hutan raya, dan taman wisata alam berdasarkan pengelompokan tujuh jenis aturan dari konsep rules-in-use Ostrom disajikan pada Tabel 1.

Tabel 1 Ringkasan analisis isi tiga peraturan pengaturan pemanfaatan air Table 1 Summary of content analysis of three regulations governing water use

\begin{tabular}{|c|c|c|c|}
\hline $\begin{array}{l}\text { Tujuh unsur } \\
\text { konsep rule in use } \\
\text { Ostrom } \\
\text { (Seven elements of } \\
\text { the concept of rule } \\
\text { in use Ostrom) }\end{array}$ & $\begin{array}{c}\text { Permen LHK No. P.18/2019 } \\
\text { (Environment and Forestry } \\
\text { Ministerial Regulations No. } \\
\text { P.18/2019) }\end{array}$ & $\begin{array}{l}\text { UU No. 17/2019 } \\
\text { (Law 17/2019) }\end{array}$ & $\begin{array}{c}\text { Permen LHK No. P.6/2020 } \\
\text { (Environment and Forestry } \\
\text { Ministerial Regulations No. } \\
\text { P.6/2020) }\end{array}$ \\
\hline 1. Aturan posisi & $\begin{array}{l}\text { Kepala UPT memproses dan } \\
\text { menerbitkan izin IPA (non } \\
\text { komersial) (Pasal } 15 \text { dan } 24) \text {. } \\
\text { Direktur Jenderal bidang } \\
\text { perlindungan hutan dan konservasi } \\
\text { serta Menteri LHK melalui Online } \\
\text { Single Submission(OSS) memproses } \\
\text { dan menerbitkan izin IUPA } \\
\text { (komersial) (Pasal } 25 \text { dan 32). }\end{array}$ & $\begin{array}{l}\text { Pemerintah Pusat, Pemerintah } \\
\text { Daerah Provinsi, Pemerintah } \\
\text { Daerah Kabupaten/Kota sesuai } \\
\text { dengan wilayah kewenangannya } \\
\text { sebagai pengatur, penetap, dan } \\
\text { pemberi izin penggunaan sumber } \\
\text { daya air (Pasal 11,14,dan 16). }\end{array}$ & $\begin{array}{l}\text { Kepala Badan Koordinasi } \\
\text { Penanaman Modal sebagai } \\
\text { penerbit perizinan berusaha } \\
\text { bidang lingkungan hidup dan } \\
\text { kehutanan (Pasal } 1 \text { ayat } 1 \text { ). }\end{array}$ \\
\hline 2. Aturan anggota & $\begin{array}{l}\text { - Tahapan perolehan IPA: } \\
\text { permohonan pemanfaatan dengan } \\
\text { memenuhi syarat administrasi } \\
\text { dan pembuatan dokumen } \\
\text { RKT, verifikasi dan penilaian, } \\
\text { penerbitan IPA dan pembangunan } \\
\text { sarana dan prasarana (Pasal 19- } \\
\text { 24). } \\
\text { - Tahapan perolehan IUPA: } \\
\text { permohonan dengan memenuhi } \\
\text { syarat administrasi dan rencana } \\
\text { kegiatan usaha, pertimbangan } \\
\text { teknis, penerbitan IUPA, } \\
\text { pemenuhan komitmen (termasuk } \\
\text { iuran dan mengurus UKL- } \\
\text { UPL), pembangunan sarana dan } \\
\text { prasarana (Pasal 25-43). }\end{array}$ & $\begin{array}{l}\text { Pengguna air non komersial untuk } \\
\text { pemenuhan kebutuhan sehari-hari } \\
\text { yang menjadikan TNGGP sebagai } \\
\text { sumber air harus mengurus } \\
\text { perizinan kepada Pemerintah } \\
\text { Pusat, Pemerintah Daerah } \\
\text { Provinsi, Pemerintah Daerah } \\
\text { Kabupaten/Kota sesuai dengan } \\
\text { wilayah kewenangannya (Pasal } 44 \\
\text { ayat 3). }\end{array}$ & $\begin{array}{l}\text { Bagi usaha pemanfaatan } \\
\text { air skala mikro, kecil, } \\
\text { menengah, dan besar di suaka } \\
\text { margasatwa, taman nasional, } \\
\text { taman wisata alam, dan } \\
\text { taman hutan raya mengajukan } \\
\text { perizinan kepada pejabat } \\
\text { penghubung dari KLHK yang } \\
\text { ditempatkan di BKPM (Pasal } \\
\text { 3). }\end{array}$ \\
\hline
\end{tabular}


Tabel 1 Lanjutan

Table 1 Continued

\begin{tabular}{|c|c|c|c|}
\hline $\begin{array}{l}\text { Tujuh unsur } \\
\text { konsep rule in use } \\
\text { Ostrom } \\
\text { (Seven elements of } \\
\text { the concept of rule } \\
\text { in use Ostrom) } \\
\end{array}$ & $\begin{array}{c}\text { Permen LHK No. P.18/2019 } \\
\text { (Environment and Forestry } \\
\text { Ministerial Regulations No. } \\
\text { P.18/2019) }\end{array}$ & $\begin{array}{l}\text { UU No. 17/2019 } \\
\text { (Law 17/2019) }\end{array}$ & $\begin{array}{c}\text { Permen LHK No. P.6/2020 } \\
\text { (Environment and Forestry } \\
\text { Ministerial Regulations No. } \\
\text { P.6/2020) }\end{array}$ \\
\hline 3. Aturan pilihan & $\begin{array}{l}\text { - Hak pemegang IPA dan IUPA: } \\
\text { melakukan kegiatan pemanfaatan } \\
\text { air sesuai izin yang diberikan } \\
\text { serta mendapatkan pelayanan dan } \\
\text { pembinaan (Pasal 37). } \\
\text { - Kewajiban pemegang IPA: } \\
\text { menyusun dan melaksanakan } \\
\text { RKT, menyampaikan laporan } \\
\text { kegiatan, memelihara kelestarian } \\
\text { sumber daya air serta kawasan } \\
\text { dan ekosistemnya (Pasal 44). } \\
\text { - Kewajiban pemegang IUPA: } \\
\text { sama dengan IPA, ditambah } \\
\text { wajib membayar Pungutan Usaha } \\
\text { Pemanfaatan Air (PUPA) (Pasal } \\
\text { 44). }\end{array}$ & $\begin{array}{l}\text { - Masyarakat berhak } \\
\text { memperoleh akses untuk } \\
\text { memanfaatkan SDA } \\
\text { (menggunakan air bagi } \\
\text { pemenuhan kebutuhan pokok } \\
\text { minimal sehari-hari, pertanian } \\
\text { rakyat, dan kegiatan bukan } \\
\text { usaha); memperoleh informasi; } \\
\text { menyatakan pendapat; serta } \\
\text { mengajukan laporan dan } \\
\text { pengaduan (Pasal 61). } \\
\text { - Masyarakat sebagai pengguna } \\
\text { air memiliki kewajiban } \\
\text { melindungi dan memelihara } \\
\text { kelangsungan fungsi SDA, } \\
\text { melindungi dan mengamankan } \\
\text { prasarana SDA, melakukan } \\
\text { usaha penghematan dalam } \\
\text { penggunaan air, melakukan } \\
\text { usaha pengendalian dan } \\
\text { pencegahan terjadinya } \\
\text { pencemaran air, serta } \\
\text { melakukan perbaikan } \\
\text { kerusakan lingkungan (Pasal } \\
\text { 62). }\end{array}$ & Tidak ada \\
\hline 4. Aturan agregasi & Tidak ada & Tidak ada & Tidak ada \\
\hline 5. Aturan informasi & Tidak ada & Tidak ada & Tidak ada \\
\hline 6. Aturan lingkup & $\begin{array}{l}\text { Pemanfaatan air dilakukan untuk } \\
\text { kegiatan non komersial dan } \\
\text { komersial (Pasal 5). Pemanfaatan } \\
\text { air non komersial meliputi } \\
\text { keperluan rumah tangga, irigasi, dan } \\
\text { kepentingan sosial (Pasal } 12 \text { ayat 1). } \\
\text { Pemanfaatan air komersial meliputi } \\
\text { air minum kemasan, perusahaan } \\
\text { daerah air minum, kegiatan industri } \\
\text { pertanian, kehutanan, perkebunan, } \\
\text { pariwisata, dan industri lainnya } \\
\text { (Pasal 13). }\end{array}$ & $\begin{array}{l}\text { - Hak rakyat atas air meliputi } \\
\text { kebutuhan pokok sehari- } \\
\text { hari, pertanian rakyat, sistem } \\
\text { penyediaan air minum (Pasal } 8 \\
\text { ayat 2). } \\
\text { - Pendayagunaan sumberdaya } \\
\text { air di kawasan suaka alam } \\
\text { dan kawasan pelestarian } \\
\text { alam dilarang kecuali bagi } \\
\text { pemenuhan kebutuhan } \\
\text { pokok sehari-hari yang tidak } \\
\text { dimanfaatkan sebagai bentuk } \\
\text { usaha (Pasal 33). }\end{array}$ & $\begin{array}{l}\text { - Izin usaha bidang } \\
\text { jasa lingkungan hutan } \\
\text { konservasi termasuk } \\
\text { pemanfaatan air di suaka } \\
\text { margasatwa, taman } \\
\text { nasional, taman wisata } \\
\text { alam, dan taman hutan raya } \\
\text { (Pasal } 2 \text { ayat 1). } \\
\text { - Kepala BKPM berpedoman } \\
\text { pada peraturan dan } \\
\text { ketentuan teknis tata cara } \\
\text { perizinan yang ditetapkan } \\
\text { oleh Menteri LHK (Pasal } \\
\text { 6). }\end{array}$ \\
\hline $\begin{array}{l}\text { 7. Aturan biaya- } \\
\text { manfaat }\end{array}$ & $\begin{array}{l}\text { - Sumber pendanaan pembangunan } \\
\text { sarana dan prasarana pemanfaatan } \\
\text { air direncanakan oleh pemohon } \\
\text { izin dan dimasukkan ke dalam } \\
\text { rencana kegiatan (Pasal } 22 \text { ayat 4) } \\
\text { - Pemegang IUPA melakukan } \\
\text { pemenuhan komitmen paling } \\
\text { lama satu tahun setelah menerima } \\
\text { perintah, salah satunya memenuhi } \\
\text { pembayaran iuran IUPA (Pasal } \\
\text { 36). }\end{array}$ & $\begin{array}{l}\text { Pendanaan pengelolaan sumber } \\
\text { daya air dapat bersumber dari } \\
\text { APBN, APBD, dan sumber } \\
\text { lain yang sah sesuai peraturan } \\
\text { perundang-undangan (Pasal } 57 \\
\text { ayat 3). }\end{array}$ & Tidak ada \\
\hline
\end{tabular}




\section{Aturan Posisi}

Aturan posisi (position rules) adalah jenis peraturan yang mengatur keberadaan partisipan yang menduduki setiap posisi di dalam suatu arena aksi (Ostrom, 2005). Menurut Permen LHK No. P.18/2019, Kepala UPT sesuai dengan kewenangannya memiliki wewenang memproses dan menerbitkan IPA yaitu izin bagi pemanfaatan non komersial meliputi pemanfaatan air untuk pemenuhan keperluan rumah tangga dan kepentingan sosial. Sementara itu, kewenangan sebagai pemrosesan dan penerbit IUPA atau izin bagi pemanfaatan komersial dipegang oleh Direktur Jenderal bidang perlindungan hutan dan konservasi serta Menteri LHK melalui OSS.

UU No. 17/2019 mengatur Pemerintah Pusat, Pemerintah Daerah Provinsi, Pemerintah Daerah Kabupaten/Kota sesuai dengan wilayah kewenangannya sebagai pengatur, penetap, dan pemberi izin penggunaan sumber daya air. Peraturan ini membatasi pemanfaatan air di KSA dan KPA hanya untuk non komersial. Menurut Permen LHK No. P.46/2016 taman nasional termasuk dalam KPA. Menurut peraturan ini pemanfaat air non komersial atau masyarakat untuk pemenuhan kebutuhan sehari-hari yang menjadikan TNGGP sebagai sumber air harus mengurus perizinan ke Pemerintah Daerah.

Sementara itu, Permen LHK No. P.6/2020 mengatur perizinan pemanfaatan air yaitu penerbitan perizinan berusaha bidang lingkungan hidup dan kehutanan dilimpahkan kepada Kepala BKPM. Pasal 6 menyebutkan bahwa Kepala BKPM berpedoman pada peraturan dan ketentuan teknis tata cara perizinan yang ditetapkan oleh Menteri LHK. Ketidakpastian dalam pengajuan dan penerbitan izin dapat membuat partisipan bimbang dalam menentukan tindakan. Para partisipan harus mendapat kepastian hukum mengenai kewenangan penerbitan izin sehingga pemerintah sebaiknya merevisi peraturan-peraturan tersebut agar selaras.

\section{Aturan Keanggotaan}

Aturan keanggotaan (boundary rules) adalah peraturan tentang persyaratan dan cara partisipan masuk atau meninggalkan posisi tertentu di dalam suatu arena aksi (Ostrom, 2005). Permen LHK No. P.18/2019 mengatur sistematika perizinan pemanfaatan air untuk kegiatan non komersial dan komersial. Pemanfaatan air yang diperuntukkan bagi kegiatan nonkomersial meliputi pemanfaatan air untuk pemenuhan keperluan rumah tangga dan kepentingan sosial sehingga pengguna dalam bentuk unit kelompok atau desa harus memiliki IPA. Pemanfaatan air yang diperuntukkan bagi kegiatan komersial meliputi air minum dalam kemasan; perusahaan daerah air minum; atau kegiatan industri pertanian, kehutanan, perkebunan, pariwisata dan industri lainnya sehingga pengguna harus memiliki IUPA.

Tahapan perolehan IPA antara lain permohonan pemanfaatan dengan memenuhi syarat administrasi dan pembuatan dokumen Rencana Kerja Tahunan (RKT), verifikasi dan penilaian, penerbitan IPA, serta pembangunan sarana dan prasarana. Tahapan perolehan IUPA antara lain permohonan pemanfaatan dengan memenuhi syarat administrasi dan rencana kegiatan usaha, pertimbangan teknis, penerbitan IUPA, pemenuhan komitmen (termasuk iuran dan mengurus UKL-UPL), serta pembangunan sarana dan prasarana. IPA diterbitkan oleh BBTNGGP sedangkan IUPA diterbitkan oleh Menteri LHK melalui OSS. Jangka waktu IPA ialah 5 tahun, sementara jangka waktu IUPA ialah 10 tahun.

Sementara itu UU No. 17 tahun 2019 mengatur bahwa pengguna air non komersial untuk pemenuhan kebutuhan sehari-hari yang menjadikan TNGGP sebagai sumber air harus mengurus perizinan kepada Pemerintah Pusat, Pemerintah Daerah Provinsi, Pemerintah Daerah Kabupaten/Kota sesuai dengan wilayah kewenangannya. Kebijakan berbeda ditetapkan pada Permen LHK No. P.6/2020 yaitu bagi usaha pemanfaatan air skala 
mikro, kecil, menengah, dan besar di suaka margasatwa, taman nasional, taman wisata alam, dan taman hutan raya mengajukan perizinan kepada pejabat penghubung dari KLHK yang ditempatkan di BKPM. Ketiga peraturan di atas menunjukkan bahwa terdapat perbedaan pada pasal-pasal tentang aturan keanggotaan atau aturan persyaratan mendapatkan izin pemanfaatan air di kawasan konservasi.

\section{Aturan Pilihan}

Aturan pilihan (choice rules) adalah peraturan yang menentukan tindakan yang diperlukan, diizinkan, atau dilarang dilakukan oleh partisipan yang menempati posisi tertentu dalam proses pengambilan keputusan (Ostrom, 2005). Choice rules ialah aturan mengenai hak dan kewajiban.

Hak pemegang IPA dan IUPA yang diatur dalam Permen LHK No. P.18/2019 yaitu melakukan kegiatan pemanfaatan air sesuai izin yang diberikan serta mendapatkan pelayanan dan pembinaan. Permen LHK tersebut mengatur kewajiban pemegang IPA yaitu menyusun dan melaksanakan RKT, menyampaikan laporan kegiatan, memelihara kelestarian sumber daya air serta kawasan dan ekosistemnya. Kewajiban pemegang IUPA yaitu sama dengan kewajiban pemegang IPA, ditambah dengan wajib membayar Pungutan Usaha Pemanfaatan Air (PUPA).

Dalam melaksanakan pengelolaan sumber daya air, UU 17/19 mengatur masyarakat berhak memperoleh akses untuk memanfaatkan sumber daya air; menggunakan air bagi pemenuhan kebutuhan pokok minimal sehari-hari, pertanian rakyat, dan kegiatan bukan usaha; memperoleh manfaat; memperoleh informasi; menyatakan pendapat; serta mengajukan laporan dan pengaduan kepada pihak yang berwenang terhadap berbagai masalah sumber daya air yang merugikan kehidupannya. Selanjutnya, UU 17/19 mengatur bahwa masyarakat sebagai pengguna air memiliki kewajiban melindungi dan memelihara kelangsungan fungsi sumber daya air, melindungi dan mengamankan prasarana sumber daya air, melakukan usaha penghematan dalam penggunaan air, melakukan usaha pengendalian dan pencegahan terjadinya pencemaran air, serta melakukan perbaikan kerusakan lingkungan yang disebabkan oleh kegiatan yang dilakukan.

Permen LHK No. P.6/2020 tidak mengatur hak dan kewajiban dalam pemanfataan air di kawasan konservasi. Pasal-pasal yang memuat tentang aturan pilihan atau aturan tindakan yang diperlukan dan diizinkan dalam Permen LHK No. P.18/2019 dan UU No. 17/19 secara umum selaras, mencakup hak untuk memanfaatkan air sesuai peraturan dan kewajiban untuk menjaga kelestarian sumber daya air.

\section{Aturan Agregasi}

Aturan agregasi (agregation rules) adalah peraturan tentang jenis tindakan tertentu yang dilakukan pada tahap pengambilan keputusan (Ostrom, 2005). Aturan agregasi mengatur bagaimana cara pengambilan keputusan di dalam suatu kelompok atau organisasi, apakah diserahkan kepada seseorang yang memiliki posisi tertentu atau melalui mekanisme lain yang melibatkan seluruh partisipan.

Hasil analisis pasal dalam ketiga peraturan menunjukkan bahwa belum ada aturan agregasi. Hal ini merupakan suatu kelemahan peraturan-peraturan tersebut mengingat pentingnya mekanisme "jalan keluar" ketika terjadi ketidakmufakatan antara partisipan.

\section{Aturan Informasi}

Aturan informasi (information rules) adalah peraturan yang mengatur tingkat informasi yang tersedia, mengotorisasi saluran informasi, menetapkan kewajiban, izin, atau larangan untuk berkomunikasi dengan partisipan pada tahap keputusan tertentu dan menetapkan bahasa yang digunakan dalam berkomunikasi (Ostrom, 2005). Berdasarkan analisis pasal pada ketiga peraturan, tidak ditemukan pasal-pasal tentang 
aturan informasi atau mekanisme bagaimana informasi dikirim atau diterima.

Mekanisme penyampaian informasi mengenai proses perizinan pemanfaatan air diserahkan kepada Balai Besar yang mengelola kawasan konservasi. Situasi umum arena aksi menggambarkan bahwa tidak semua masyarakat, baik pengguna nonkomersial maupun komersial memahami aturan perizinan pemanfaatan air sehingga mekanisme bagaimana informasi dikirim atau diterima oleh para partisipan sebaiknya diatur dan ditekankan dalam peraturan.

\section{Aturan Lingkup}

Aturan lingkup (scope rules) adalah peraturan yang mengatur tindakan atau keadaan yang memengaruhi variabel hasil yang "harus", "tidak boleh", atau "mungkin" terpengaruh sebagai akibat dari tindakan yang diambil dalam suatu situasi (Ostrom, 2005). Dalam Permen LHK No. P.18/2019, pemanfaatan air diklasifikasikan menjadi kegiatan non komersial dan komersial. Pemanfaatan air non komersial meliputi keperluan rumah tangga, irigasi, dan kepentingan sosial. Pemanfaatan air komersial meliputi air minum kemasan; perusahaan daerah air minum; kegiatan industri pertanian, kehutanan, perkebunan, pariwisata, dan industri lainnya.

Undang-Undang No. 17/2019 terbit dengan ketetapan berbeda yaitu hak rakyat atas air meliputi kebutuhan pokok seharihari, pertanian rakyat, sistem penyediaan air minum, sedangkan pendayagunaan sumber daya air di kawasan suaka alam dan kawasan pelestarian alam dilarang, kecuali bagi pemenuhan kebutuhan pokok sehari-hari yang tidak dimanfaatkan sebagai bentuk usaha. Sementara itu, peraturan penerbitan izin usaha bidang lingkungan hidup dan kehutanan mencantumkan usaha bidang jasa lingkungan hutan konservasi termasuk pemanfaatan air di suaka margasatwa, taman nasional, taman wisata alam, dan taman hutan raya.

Permen LHK No. P.6/2020 hanya mengatur izin usaha pemanfaatan air skala mikro, kecil, menengah, dan besar di suaka margasatwa, taman nasional, taman wisata alam, dan taman hutan raya bidang pemanfaatan jasa lingkungan hutan konservasi. Berdasarkan hasil wawancara, diperoleh gambaran bahwa pemanfaatan air komersial yang berasal dari TNGGP tidak dapat dihindari. Alihalih membatasi penggunaan sumber daya air di KPA dan KSA untuk kegiatan usaha, sebaiknya pemerintah tetap mempertahankan regulasi pemanfaatan air untuk kegiatan usaha. Jika peraturan membatasi tetapi fakta yang terjadi ialah pemanfaatan air tidak dapat dihindari maka hal ini dapat menimbulkan banyaknya pemanfaatan air ilegal.

\section{Aturan Biaya-Manfaat}

Aturan biaya-manfaat (pay-off rules) adalah peraturan tentang bagaimana manfaat dan biaya yang diperlukan, diizinkan, atau dilarang didistribusikan kepada para partisipan (Ostrom, 2005). Menurut Permen LHK No. P.18/2019, sumber pendanaan pembangunan sarana dan prasarana pemanfaatan air direncanakan oleh pemohon izin dan dimasukkan ke dalam rencana kegiatan.

Peraturan ini juga mengatur pemegang IUPA memiliki kewajiban membayar iuran IUPA sebagai salah satu pemenuhan komitmen, paling lama satu tahun setelah menerima perintah. Berdasarkan wawancara dengan staf BBTNGGP dan Kepala Resor, banyaknya pengguna komersial yang tidak mengurus izin karena keberatan dengan besaran pungutan dan iuran yang harus dibayarkan. Sampai penelitian selesai dilakukan, belum ada tindak lanjut terhadap pengusaha yang mengambil air secara ilegal dari kawasan TNGGP. Sebaiknya dilakukan diskusi dengan para pengusaha agar memiliki kesepakatan mengenai keseimbangan biaya yang ditanggung dan manfaat yang diperoleh sehingga para pengusaha bersedia mengurus izin dan memanfaatkan air secara legal.

Berbeda dengan peraturan ini, UU No. 17/2019 yang mengatur sumber daya alam hanya diperuntukkan bagi kegiatan non komersial, pendanaan pengelolaan sumber 
daya air dapat bersumber dari APBN, APBD, dan sumber lain yang sah sesuai peraturan perundang-undangan. Menurut Knox \& Meinzen-Dick (2001), salah satu insentif yang paling penting bagi pengelolaan sumber daya hutan ialah pemberian hakhak (property rights) yang diperlukan untuk mendorong partisipan bersedia menanggung biaya pengelolaan sumber daya alam. Apabila terdapat kewajiban insentif berupa pembayaran atau pemeliharaan maka partisipan cenderung merawat sumber daya sehingga lebih lestari dan berkelanjutan.

Berdasarkan hasil analisis menggunakan konsep rules-in-use Ostrom terhadap pasalpasal yang berkaitan dengan perizinan pemanfaatan air di TNGGP, ditemukan beberapa kelemahan. Ringkasan kelemahankelemahan peraturan, analisis akar permasalahan, dan arahan terhadap kebijakan disajikan pada Tabel 2. MenurutKartodihardjo (2006a), lemahnya penguatan kelembagaan telah terbukti diikuti oleh kegagalan implementasi kebijakan untuk mencapai tujuan. Kegagalan tersebut merupakan akibat lemahnya para pengambil keputusan memahami adanya kondisi sosial yang kompleks (complex societies). Ciri complex societies yaitu keputusan yang terpusat, aliran informasi yang tinggi, koordinasi yang tinggi, instruksi oleh kewenangan formal, dan pemusatan sumber daya (Diamond, 2005).

Pendekatan yang paling sering digunakan untuk mencapai penaatan lingkungan adalah Atur dan Awasi (ADA) atau dikenal juga dengan Command and Control (CAC), sama halnya dengan peraturan perizinan pemanfaatan air ini. Pendekatan CAC mengindikasikan adanya aturan pemerintah yang menentukan bagaimana masyarakat harus bertindak. Terdapat beberapa kelemahan pendekatan CAC menurut Soemarwoto (2001) dalam Wibisana (2019). Pertama, pendekatan CAC terlalu mendasarkan diri pada pandangan bahwa perilaku anti-lingkungan dapat dilawan dengan peraturan perundang-undangan tanpa mempertimbangkan pandangan bahwa manusia selalu mencari tindakan yang menguntungkan dirinya. Kedua, pendekatan CAC bersifat top-down dan instruktif, masyarakat diharuskan melaksanakan apa yang tertulis di dalam peraturan perundangundangan menurut interpretasi Pemerintah yang seringkali tidak mempertimbangkan kondisi masyarakat saat membuat peraturan. Ketiga, pendekatan CAC bersifat kaku dan birokratis, aturan dibuat secara rinci dan detail, dimulai dari undang-undang sampai pada tingkat petunjuk pelaksanaan dan petunjuk teknis. Kekakuan ini berakibat pada tidak berkembangnya teknologi dan sistem pengelolaan lingkungan. Misalnya

Tabel 2 Ringkasan kelemahan-kelemahan peraturan, analisis akar permasalahan, dan arahan terhadap kebijakan Table 2 Summary of regulatory weaknesses, root cause analysis, and policy directions

Kelemahan peraturan berdasarkan unsur dalam rules-in-use Ostrom (Weaknesses of rules based on elements in Ostrom's rules-in-use)

1. Aturan posisi: ketidakpastian posisi pihak yang berwenang dalam pengajuan dan penerbitan izin.

2. Aturan keanggotaan: terdapat perbedaan aturan persyaratan mendapatkan izin pemanfaatan air.

3. Aturan pilihan: secara umum selaras.
Analisis akar permasalahan (Root cause analysis)

Lemahnya penguatan kelembagaan (Kartodihardjo, 2006a).

- Lemahnya para pengambil keputusan memahami adanya kondisi sosial yang kompleks (complex societies) (Diamond, 2005).
Arahan terhadap kebijakan (Policy direction)
- Para partisipan harus mendapat kepastian hukum mengenai kewenangan dan proses penerbitan izin sehingga pemerintah sebaiknya merevisi peraturan-peraturan tersebut agar selaras. 
Tabel 2 Lanjutan

Table 2 Continued

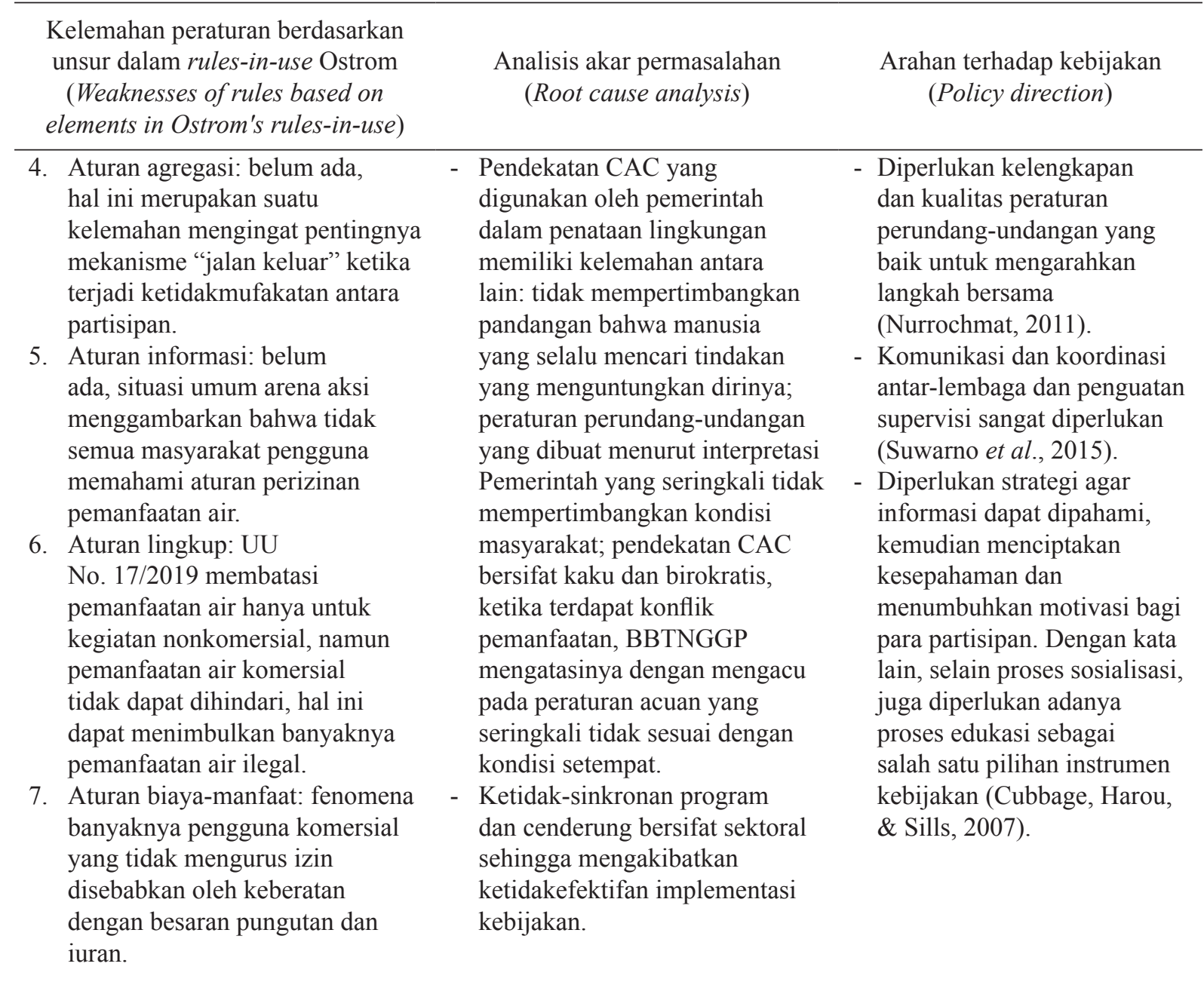

dalam konteks pemanfaatan air di TNGGP, seharusnya keleluasaan BBTNGGP dapat diberikan dalam pengelolaan pemanfaatan air, terutama jika terjadi konflik pemanfaatan sesuai dengan kondisi di lapangan. Fenomena yang terjadi, BBTNGGP mengatasinya dengan mengacu pada peraturan acuan yang seringkali tidak sesuai dengan kondisi setempat.

Bertalian dengan hal yang telah dijabarkan sebelumnya, ketidakjelasan atau ketidaksesuaian dari otoritas yang berwenang mengakibatkan adanya kesenjangan antara pemerintah pusat dan institusi daerah. Hal itu berimplikasi terjadinya ketidak-sinkronan program dan cenderung bersifat sektoral sehingga mengakibatkan ketidakefektifan implementasi kebijakan (Kartodihardjo, 2006c). Diperlukan kelengkapan dan kualitas peraturan perundang-undangan yang baik untuk mengarahkan langkah bersama (Nurrochmat, 2011). Komunikasi dan koordinasi antar-lembaga dan penguatan supervisi sangat diperlukan (Suwarno et al., 2015). Ketersediaan informasi dan kemudahan akses belum cukup, diperlukan pula strategi agar informasi tersebut dapat dipahami, kemudian menciptakan kesepahaman dan menumbuhkan motivasi bagi para partisipan. Selain proses sosialisasi, juga diperlukan adanya proses edukasi sebagai salah satu pilihan instrumen kebijakan (Cubbage, Harou, \& Sills, 2007). 


\section{Peraturan yang Terbit Setelah Undang- Undang Cipta Kerja (UUCK) Disahkan}

Hal penting yang tidak selaras pada Permen LHK No. P.18/2019 dan UU No. 17/2019 ialah bahwa UU No. 17/2019 mengatur bahwa air dari kawasan konsevasi tidak diperuntukkan bagi penggunaan komersial. Sampai pada penelitian selesai dilaksanakan, BBTNGGP masih bersikap menunggu peraturan turunan sehingga izin komersial (IUPA) yang sedang dalam proses harus ditangguhkan. Setelah UUCK disahkan pada 5 Oktober 2020, terbit Peraturan Pemerintah (PP) No. 5 tahun 2021 tentang Perizinan Berusaha Berbasis Risiko, yaitu perizinan berusaha berdasarkan tingkat risiko kegiatan usaha. Tingkat risiko berdasarkan hasil analisis risiko menentukan jenis perizinan berusaha.

Perizinan berusaha untuk kegiatan usaha dengan tingkat risiko rendah yaitu Nomor Induk Berusaha (NIB), bukti registrasi/ pendaftaran pelaku usaha untuk melakukan kegiatan usaha dan sebagai identitas bagi pelaku usaha dalam pelaksanaan kegiatan usahanya. Selanjutnya, perizinan berusaha untuk kegiatan usaha dengan tingkat risiko menengah yaitu NIB dan sertifikat standar. Sertifikat standar adalah pernyataan dan/ atau bukti pemenuhan standar pelaksanaan kegiatan usaha. Perizinan berusaha untuk kegiatan usaha dengan tingkat risiko tinggi yaitu NIB dan izin. lzin adalah persetujuan Pemerintah Pusat atau Pemerintah Daerah untuk pelaksanaan kegiatan usaha.

Pada Pasal 39 Ayat 5 disebutkan bahwa perizinan berusaha pada subsektor pemanfaatan jasa lingkungan di kawasan konservasi terdiri atas, salah satunya, pemanfaatan jasa lingkungan air yang dapat berskala mikro, kecil, menengah, dan besar. Pada lampiran peraturan disebutkan bahwa seluruh kegiatan usaha skala mikro hingga besar diklasifikasikan ke dalam kegiatan usaha dengan tingkat risiko tinggi sehingga perizinan berusaha yang harus dipenuhi yaitu NIB dan izin.
Pemanfaatan jasa lingkungan air skala mikro yaitu pemanfaatan air dengan debit kurang dari 5 liter/detik. Pemanfaatan jasa lingkungan air skala kecil yaitu pemanfaatan air dengan debit 5-20 liter/detik. Pemanfaatan jasa lingkungan air skala menengah yaitu pemanfaatan air dengan debit 20-50 liter/ detik. Pemanfaatan jasa lingkungan air skala mikro yaitu pemanfaatan air dengan debit lebih dari 50 liter/detik. Seluruh kewenangan izinnya berada pada Menteri LHK dan berlaku selama 10 tahun.

PP No. 5/2021 kembali mengatur perizinan pemanfaatan air di kawasan konservasi untuk kepentingan komersial, setelah sebelumnya UU No. 17/19 mengatur pemanfaatan air di kawasan konservasi tidak diperuntukkan bagi penggunaan komersial.

\section{KESIMPULAN DAN SARAN}

\section{A. Kesimpulan}

Berdasarkan hasil analisis isi peraturan, terdapat beberapa hal yang dapat disimpulkan. Pertama, kelemahan-kelemahan substansial peraturan pemanfaatan air, antara lain: ketidakpastian posisi pihak yang berwenang dan persyaratan dalam pengajuan dan penerbitan izin, belum adanya aturan agregasi sehingga belum ada mekanisme "jalan keluar" ketika terjadi ketidakmufakatan antara partisipan, tidak semua masyarakat pengguna memahami aturan perizinan pemanfaatan air, peraturan yang membatasi pemanfaatan air hanya untuk kegiatan non-komersial dapat menimbulkan banyaknya pemanfaatan air ilegal, serta banyaknya pengguna komersial yang tidak mengurus izin disebabkan oleh keberatan dengan besaran pungutan dan iuran.

Kedua, kelemahan-kelemahan tersebut diduga disebabkan oleh ketidak-sinkronan program antara peraturan dan implementasi yang menunjukkan lemahnya penguatan kelembagaan, pendekatan CAC yang digunakan oleh pemerintah dalam penataan lingkungan memiliki kelemahan, terutama dalam hal peraturan perundang-undangan 
yang dibuat menurut interpretasi Pemerintah seringkali tidak mempertimbangkan kondisi masyarakat, pendekatan CAC bersifat kaku dan birokratis sehingga ketika terdapat konflik pemanfaatan maka diatasi dengan mengacu pada peraturan yang seringkali tidak sesuai dengan kondisi setempat.

\section{B. Saran}

Untuk mengatasi kelemahan-kelemahan peraturan maka diperlukan perbaikan kelembagaan melalui komunikasi dan koordinasi antara seluruh pihak-pihak yang terkait serta penguatan supervisi dan strategi agar tercipta kesepahaman antar-partisipan. Jika perbaikan kelembagaan telah dilakukan dan peraturan yang ditetapkan dipahami oleh seluruh partisipan maka tingkat kesesuaian peraturan dengan implementasi di lapangan akan tinggi.

\section{UCAPAN TERIMA KASIH (ACKNOWLEDGEMENT)}

Terima kasih kepada Balai Besar Taman Nasional Gunung Gede Pangrango dan Institut Pertanian Bogor yang telah mendukung terlaksananya penelitian ini.

\section{DAFTAR PUSTAKA}

Anwar, A. \& Rustiadi, E. (2000). Natural resources management problems and economic policies for damage control. Bogor: IPB University. Retrieved from http://repository.ipb.ac.id/ handle/123456789/24803.

Birkland, T. A. (2001). An introduction to the policy process: theories, concepts, and models of public policy making. New York, US: M.E. Sharpe.

Cole, D. H. (2017). Laws, norms, and the institutional analysis and development framework. Journal of Institutional Economics, 13(4), 829-847. https:// doi.org/10.1017/s1744137417000030.

Cubbage, F., Harou, P., \& Sills, R. (2007). Policy instruments to enhance multi-functional forest management. Forest Policy and Economics, 9, $833-851$.

Diamond, J. (2005). Collapse: how societies choose to fail or survive. New York, US: Viking Press.

Dunn, W. (2003). Pengantar analisis kebijakan publik. Yogyakarta, ID: Gadjah Mada University Press.
FORPELA. (2009). Laporan tahunan 2009 FORPELATaman Nasional Gunung Gede Pangrango. Bogor: BBTNGGP.

Kartodihardjo, H. (2006a). Masalah kapasitas kelembagaan dan arah kebijakan kehutanan: studi tiga kasus. Manajemen Hutan Tropika, $X I I(3), 14-25$.

Kartodihardjo, H. (2006b). Economics and forest management institutions: further analysis of forestry business policy analysis. Bogor, id: Institute for Deveopment Economics of Agriculture and Rural Areas (IDEALS).

Kartodihardjo, H. (2006c). Masalah kelembagaan dan arah kebijakan rehabilitasi hutan dan lahan. Jurnal Analisis Kebijakan Kehutanan, 3(1), 2941.

Knox, A. \& Meinzen-Dick, R. (2001). Collective action, property rights, and devolution of natural resource management: a conceptual framework. Washington DC, USA: IFPRI.

Nurrochmat, D. R. (2011). Review infra-structure framework and mechanism related to SFM as important option in reducing emission from deforestation and forest degradation. Bogor: IPB University. Retrieved from https://repository.ipb. ac.id/jspui/handle/123456789/82947.

Ostrom, E. (2005). Understanding institutional diversity. Princeton, US: Princeton University Press.

Ostrom, E. (2008). Institutions and the environment. Economic Policy, 28(3), 24-31. https://doi. org/10.1111/1468-0327.00036.

Ostrom, E. \& Crawford, S. (2005). A grammar of institutions (Understand). Princeton, NJ: Princeton University Press.

Ostrom, E., Gardner, G., \&Walker, J. (2006). Rule, games \& common-pool resources. Michigan, US: University of Michigan Press.

Peters. (2000). The politics of bureaucracy. London UK: Routledge.

Sabatier, P. A., Leach, W., Lubell, M., \& Pelkey, N. (2005). Theoretical frame-works explaining partnership success. Cambridge, MA: MIT Press.

Suwarno, E., Kartodihardjo, H., Kolopaking, L. M., \& Soedomo, S. (2015). Penggunaan konsep rules-in-use Ostrom. Jurnal Analisis Kebijakan Kehutanan, 12(38), 13-27.

Weeden, B. C. \& Chow, T. (2012). Taking a commonpool resources approach to space sustainability: a framework and potential policies. Space Policy, 28(3), 166-172.

Wibisana, A. G. (2019). Instrumen ekonomi, command and control, dan instrumen lainnya: kawan atau lawan? Suatu tinjauan berdasarkan smart regulation. Bina Hukum Lingkungan, 4(1), 172197. 